ФОРМУВАННЯ ЕТИЧНОЇ КОМПЕТЕНТНОСТІ МАЙБУТНІХ ФАХІВЦІВ У ПОЗААУДИТОРНІЙ ДІЯЛЬНОСТІ

\title{
FORMATION OF ETHICAL COMPETENCE OF FUTURE SPECIALISTS IN EXTRACURRICULAR ACTIVITIES
}

\begin{abstract}
Стаття присвячена одній з актуальних проблем - формуванню етичної компетентності у майбутніх фрахівців. У роботі розкрито зміст поняття «етична компетентність майбутнього фрахівця», яку визначено як інтегральне особистісне утворення, що характеризується ціннісними орієнтаціями, знаннями у сфрері етики та є результатом особистісно-професійного розвитку людини, виявляється у ступені відповідності або невідповідності етичної поведінки фрахівця нормам етики та професійним стандартам. Досліджено основні поведінкові характеристики етичної компетентності студента. Важливими характеристиками етичної компетентності студента $є$ иіннісні орієнтації, оскільки вони детермінують його майбутню поведінку, забезпечуючи зміст і спрямованість діяльності, надають сенс профресійним діям. Формування позитивної мотивації до навчання визначено провідним стимулом набуття майбутніми фахівцями етичних знань, умінь і навичок, розвитку морально-духовних якостей.

Визначено змістову структуру етичної компетентності майбутнього фрахівця. Структура етичної компетентності включає гностичний, мотиваційно-ціннісний, діяльнісний компоненти. Гностичний компонент характеризується усвідомленням необхінності прояву етичної компетентності майбутнім фрахівцем, орієнтацією на базові етичні цінності, розвиток моральних якостей. Мотиваційно-ціннісний компонент виражається у потребі виявляти етичну компетентність у повсякденній життєдіяльності, орієнтації на формування етичних цінностей. Діяльнісний компонент передбачає розвиток етичних умінь $і$ навичок, дотримання етичних норм у взаєминах 3 навколишніми, самоконтроль та саморегуляцію поведінки. Зазначені компоненти перебувають у тісному взаємозв'язку та впливають один на одного. До основних завдань формування етичної компетентності майбутніх фрахівців віднесено: розширення морально-етичних знань про етичну компетентність; розвиток у студентів позитивної мотивації до формування і виявлення етичної компетентності у повсякденній життєдіяльності та майбутній професійній діяльності.
\end{abstract}

Тернопільська В.І. д-р пед. наук, профресор, професор кафедри соціальної освіти та соціальної роботи

Національного педагогічного університету імені М.П. Драгоманова
Ключові слова: етика, етичні цінності, етична компетентність, студенти, майбутні фрахівці, мотивація, ціннісні орієнтації, позааудиторна діяльність.

The article is devoted to one of the urgent problems of formation of ethical competence in future specialists. The article reveals the meaning of the concept of "ethical competence of the future specialist". Ethical competence is defined as an integral personal education, characterized by values, knowledge in the field of ethics and is the result of their personal and professional development, is manifested in the degree of compliance or non-compliance of ethical behavior with ethics and professional standards. The main behavioral characteristics of ethical competence of the individual are revealed. Important characteristics of the student's ethical competence are value orientations, as they determine his future behavior, ensuring the content and direction of activities, give meaning to professional actions. The formation of positive motivation for learning is determined by the leading incentive for future professionals to acquire ethical knowledge, skills and abilities, the development of moral and spiritual qualities.

The semantic structure of ethical competence of the future specialist is determined. The structure of ethical competence includes gnostic, motivational-value, activity components. The Gnostic component is characterized by awareness of the need for aesthetic competence of the future specialist, focus on basic ethical values, the development of moral qualities. Motivational and value component is manifested in the need to show ethical competence in everyday life, focus on the formation of ethical values. The activity component involves the development of ethical skills, adherence to ethical norms in relationships with others, self-control and self-regulation of behavior. These components are closely interrelated and interact with each other. The main tasks of the formation of ethical competence of future professionals include: expanding moral and ethical knowledge about ethical competence; development of students' positive motivation to form and identify ethical competence in everyday life in future professional activities.

Key words: ethics, ethical values, ethical competence, students, future professionals, motivation, empathy, value orientations, extracurricular activities.
Постановка проблеми в загальному вигляді. Процеси глобалізації та євроінтеграції, демократичні перетворення у соціально-політичному житті України детермінують розвиток етичних цінностей громадян, які виступають соціально значущим орієнтиром їхньої діяльності та забезпечують духовно-моральну єдність суспільства, відповідний рівень самосвідомості й організованості його членів. При цьому особлива увага приділяється важливим моральним якостям, етичній компетентності майбутнього фрахівця, які є регулятором його дій, забезпечують вибір ним свідомої етичної поведінки згідно з нормами професійної етики.

Аналіз останніх досліджень і публікацій. Проблема моральності, етики у взаєминах студентської молоді знайшла своє підтвердження у нормативних документах: Конституції України, Законах України «Про освіту» (2017р.), «Про вищу освіту» (2014р.), Національній стратегії розвитку освіти в Україні на 2012-2021 рр., Концепції 
національно-патріотичного виховання дітей та молоді (2015 р.), Концепції реалізації державної політикиусорерірефрормуваннязагальної середньої освіти «Нова українськашкола» наперіоддо 2029 р.

Теоретичні засади етичної компетентності наведені у роботах Е. Дюркгейма, Л.І. Грядунова, О.Ф. Плахотного, А.С. Шабурова, О.А. Безрукової, А.І. Ореховського, Є.М. Пенькова. У педагогічному аспекті проблеми фрормування моральних якостей, етичної компетентності особистості обґрунтовані І.Д. Бехом, В.О. Сухомлинським, О.І. Донцовим, К.О. Журбою, В.А. Киричок, О.О. Романовським, І.В. Сопівник, Т.В. Куницькою, В.І. Тернопільською, Л.Л. Хоружою, І.М. Шкільною, К.І. Чорною, І.О. Синицею, І.І. Чорнокозовим. Результати дослідної діяльності вищезазначених фрахівців були основоположними у розробці концептуальних засад нашого дослідження.

Виділення не вирішених раніше частин загальної проблеми. Наявність значного інтересу до проблеми фрормування етичної компетентності майбутніх фрахівців та відсутність фрундаментальних досліджень із зазначеного напряму зумовили необхідність організації дослідницької діяльності.

Мета статті - розкрити зміст поняття «етична компетентність» та визначити форми, методи фрормування цього інтегрального утворення у майбутніх фрахівців.

Виклад основного матеріалу. Етична компетентність, на нашу думку, є інтегральним особистісним утворенням майбутнього фрахівця, що характеризується ціннісними орієнтаціями, знаннями у сорері етики та є результатом особистіснопрофресійного розвитку, виявляється у ступені відповідності або невідповідності етичної поведінки фрахівця нормам етики і професійним стандартам.

Аналіз наукових джерел дозволяє стверджувати, що етична компетентність є складним утворенням ціннісних, діяльнісних, особистісних аспектів і не має однозначного та універсального визначення. Однак їі можна проаналізувати й визначити у контексті певної сорери людського життя [8]. Незважаючи на широке науково-практичне використання, категорія «етична компетентність» залишається концептуально невизначеною, по-різному інтерпретується, що безпосередньо позначається на її особистісно-перетворювальній дієвості. Зокрема, вчені акцентують увагу на знаннях 3 етики, певному наборі моральних якостей фахівця, його готовності до етично адекватної поведінки в ситуаціях морального вибору. При цьому етична компетентність $€$ складником професійної компетентності фрахівця.

Важливими характеристиками етичної компетентності студента виступають ціннісні орієнтації, оскільки вони детермінують його майбутню поведінку, забезпечуючи зміст і спрямованість діяльності, надають сенс профресійним діям. Формування позитивної мотивації до навчання є провідним стимулом набуття майбутніми фрахівцями етичних знань, умінь і навичок, розвитку моральнодуховних якостей.

Водночас юнацький вік характеризується суперечностями між прагненням до істини та невмінням зрозуміти ії моральну сутність, прагненням до позитивного ідеалу, самостійності та відсутністю здатності його досягнення, небажанням бути «виховуваним» і недостатнім розвитком умінь самовиховання [5]. Слід зауважити, що детермінантною розвитку морально досконалої особистості майбутнього фрахівця $є$ його професійно-пізнавальна діяльність у закладі вищої освіти, самоосвіта, самовиховання.

Цінною для нашого дослідження є ідея І.Д. Кочетовоїпроте,щоморальнізнаннялежатьвосновікомпетентностей, вибору людиною поведінкових стратегій та обумовлюють розвиток гнучкого мислення, відповідальної поведінки, умінь успішної взаємодії 3 навколишніми, здатності узгоджувати, розуміти, адекватно діяти в будь-яких життєвих ситуаціях [4].

Зазначимо, що складниками етичної компетентності індивіда $є$ такі імперативи, як моральна оцінка, моральний вибір та обов'язок. При цьому моральна оцінка виявляється у здатності індивіда розпізнавати добро, переживати його на емоційному рівні, а також чинити відповідно до власних уявлень про моральні цінності. Здатність до моральної оцінки є основою непримиримого ставлення та протистояння аморальним впливам. Вона включає оцінку і самооцінку, що детермінує розвиток моральної свідомості й самосвідомості індивіда. У цьому контексті етика та мораль $є$ основою світобачення індивіда, узгодження суспільних вимог 3 особистими етичними переконаннями, цінностями і мотивами діяльності. Значущість моральної оцінки у фрормуванні етичної компетентності полягає в тому, що вона характеризує здатність особистості діяти не з примусу, а з власного переконання, моральної потреби. Моральний або етичний вибір індивіда регулюється його інтелектуальними і вольовими якостями та забезпечує узгодження моральних вимог суспільства з моральними потребами самого індивіда.

До того ж моральний вибір здійснюється через моральну оцінку, самоконтроль, розуміння причинно-наслідкових зв'язків. До основних характеристик морального вибору особистості належать: 1) розуміння морального вибору як діяльнісноповедінкового акту; 2) автономність суб'єкта; 3) пріоритетність цінностей суб'єкта; 4) самовизначення особистості в системі відносин і поведінкових координат; 5) моральний вибір саморегулюється ієрархією цінностей і регулюється моральними нормами [2]. 
Згідно з твердженням Т.П. Ємельянової [3] обов'язок характеризує ставлення особистості до суспільства через вимоги, що висуваються до неї, відповідно до її обов'язку. В ситуації, коли обов'язок особистості узгоджується 3 моральними чи професійними вимогами, відповідальність визначає, як саме він втілюється у практичній діяльності.

Слід зазначити, що покладання на себе обов'язку $є$ свідченням сорормованості етичної компетентності особистості, добровільного бажання щось зробити заради інших людей, зацікавленості у результатах своєї діяльності.

Структура етичної компетентності включає гностичний, мотиваційно-ціннісний, діяльнісний компоненти. Гностичний компонент характеризується усвідомленням необхідності прояву етичної компетентності майбутнім фрахівцем, орієнтацією на базові етичні цінності, розвиток моральних якостей. Мотиваційно-ціннісний компонент виражається у потребі виявляти етичну компетентність у повсякденній життєдіяльності, орієнтації на фрормування етичних цінностей. Діяльнісний компонент передбачає розвиток етичних умінь і навичок, дотримання етичних норм у взаєминах із навколишніми, самоконтроль та саморегуляцію поведінки. Зазначені компоненти перебувають у тісному взаємозв'язку та впливають один на одного.

Завданнями формування етичної компетентності майбутніх фрахівців є: розширення моральноетичних знань про етичну компетентність; розвиток у студентів позитивної мотивації до фрормування і виявлення етичної компетентності у повсякденній життєдіяльності та майбутній професійній діяльності. Так, методична реалізація компетентнісного підходу у вищій школі пов'язана з використанням таких педагогічних засобів, що своєчасно створюватимуть в освітньому процесі ситуації, за яких відбуватиметься синтез набутих знань, умінь та способів практичної діяльності [1]. Формування етичної компетентності майбутніх фрахівців виявляється у змістовому наповненні аудиторної та позааудиторної діяльності (форми, методи, засоби), застосуванні інноваційних технологій. Під час включення студентів у різні види позааудиторної діяльності відбувається фрормування етичної компетентності, засвоєння ними певного досвіду, моральних якостей, які виявляються у взаємодії з іншими людьми. Самеупозааудиторній діяльності відбувається міжособистісне неформальне спілкування, взаємодія студентів, етичне збагачення, духовне та професійне становлення особистості.

Профресійна підготовка майбутніх фрахівців на основі компетентнісного підходу дає змогу фрормувати у них професійно значущі моральні якості, етичну компетентність. На думку І.Д. Беха [1], компетентнісний підхід репрезентується сорормованістю у суб'єкта наукового поняття «компетентність» як єдності, де науково орієнтована основа дії визначає логіку її практичного виконання, що полягає в інтелектуально-моральній саморегуляції, спрямованій на ефективне подолання певних життєвих проблем. До компетентності цього рівня спонукає прагнення до самоствердження, почуття гідності, соціальна мотивація тощо. Компетентність вищого рівня безпосередньо залежить від якості наукових здобутків, які трансформуються в систему компетентностей. Компетентнісний підхід має забезпечити несуперечливу трансфрормацію суб'єкта навчання у суб'єкт суспільної практики, тобто цілеспрямоване перетворення дійсності у суб'єкт-об'єктній (виробничій) і суб'єктсуб'єктній (людських відносинах) фрормах.

Слід зазначити, що куратор академічної групи $€$ ключовою фрігурою в освітньому процесі закладу вищої освіти, його особистий приклад, позиція, етика поведінки, стиль взаємодії зі студентами мають суттєвий вплив на формування етичної компетентності студентів, розуміння ними їі сутності та проявів.

Ефрективною фрормою вважаємо кураторські години: «Прийняття моральних рішень», «Неетична поведінка та її наслідки». Метою цих занять $€$ розширення уявлень студентів про етику, моральні якості, етичну компетентність. Виховна година передбачала вирішення проблемних ситуацій, пов'язаних із дотриманням етичних норм студентами. Розв'язанню суперечливих ситуацій передувала розробка стратегії етичних рішень. Слід відзначити ефективність вправи «Дерево рішень», перевагою якої є її варіативність і гнучкість та демонстрація причинно-наслідкових зв'язків. Виконання вправи «Дерево рішень» сприяло оволодінню студентами навичками прийняття етичних рішень, вибору оптимального рішення відповідно до ситуації. Гра «Що в основі наших етичних рішень?» допомагала закріпити етичні вміння та навички студентів.

Виховна година «Неетична поведінка та іiї наслідки» сприяла фрормуванню ціннісного ставлення до себе та інших, розвитку емпатії, здатності передбачати наслідки своїх дій, фрормуванню вмінь етичної поведінки студентів. Зокрема, проведена мінідискусія показала, як розуміють студенти поняття «неетична поведінка». Так, вони охарактеризували неетичну поведінку як нехтування етичними цінностями та усталеними моральними правилами.

Привертає увагу в контексті формування етичної компетентності активна участь майбутніх фрахівців в імітаційній грі «Крамниця цінностей». Метою гри є вивчення рівня розвитку моральної свідомості, етичних цінностей, етичної компетентності студентської молоді. На основі імітаційної моделі створювалася ігрова ситуація купівлі-продажу етичних цінностей, які необхідні для успішної професійної діяльності, налагодження позитивних 
особистісних взаємин та визначення негативних цінностей, що не сприяють встановленню позитивних відносин, успішній професійній діяльності. 3 імітаційною моделлю в рольовій грі присутній об'єкт імітації, який представлений конкретною діяльністю. Були визначені директор крамниці (куратор академічної групи), який продавав етичні цінності (якості); покупці (студенти), які купували етичні цінності; незалежні експерти (студенти). Гра проводилась у три етапи: підготовчий, змістовно-діяльнісний, результативно-оцінювальний. На підготовчому етапі студенти розподілялися на кілька груп по 5-7 осіб у кожній. Студенти-покупці «купували» у крамниці етичні цінності, яких у них не вистачало для успішної профресійної діяльності, налагодження позитивних особистісних взаємин, в обмін на свої негативні цінності, якості або ж на властиві їм позитивні. Далі куратор групи разом зі студентами обговорювали та розробляли програму привласнення придбаних у крамниці етичних цінностей, закріплення їх у власній поведінці. Під час результативно-оцінювального етапу гри студенти підбивали підсумки «купівлі-продажу» цінностей. Обговорюючи результати гри, майбутні фахівці обмірковували та усвідомлювали набутий емоційний досвід, формували стратегію подальшої етичної поведінки.

Ефективним засобом фрормування етичної компетентності майбутніх фрахівців $€$ їхня участь у проєктах. До важливих умов успішності проєктів можна віднести: наукову новизну і практичну значущість проєкту для майбутньої профресійної діяльності; бажання студентів самостійно досліджувати зазначену проблему; чітке визначення мети, завдань та структури дослідження; конструктивну взаємодію з іншими учасниками проєкту; захист основних положень проєкту та його обговорення.

Проведення методичної роботи з викладачами та кураторами студентських груп сприяло розширенню їхніх знань про етичну компетентність, які спонукали до педагогічної творчості, використання як традиційних, так й інноваційних фрорм, методів виховання. Методична робота з кураторами академічних груп закладів вищої освіти здійснювалася на: теоретико-методологічному рівні (ознайомлення з методологічними та концептуальними засадами і сучасними дослідженнями у психолого-педагогічній науці); морально-етичному рівні (організація освітньої діяльності у закладі вищої освіти на основі гуманістичної етики і моралі); практичному рівні (вміння ефрективно застосовувати різноманітні форми і методи роботи); особистісному рівні (знання вікових, індивідуальних особливостей студентів).

Висновки. Отже, освітній процес у закладі вищої освіти є вирішальним у формуванні етичної компетентності майбутніх фрахівців, розвитку в них ціннісних орієнтацій. Важливою характеристикою студентського віку $є$ ієрархічність мотивів і становлення стійкого ядра ціннісних орієнтацій, які детермінують їхню майбутню професійну діяльність. Етичні цінності пов'язані 3 емоційно-виховними механізмами психіки майбутнього фахівця, регулюють психічні, розумові й поведінкові процеси та впливають на фрормування у нього профресійних знань, умінь і навичок, забезпечують вибір свідомої етичної поведінки згідно з професійними нормами.

\section{БІБЛІОГРАФІЧНИЙ СПИСОК:}

1. Бех І.Д. Вибрані наукові праці. Виховання особистості. Т. 2. Чернівці : Букрек, 2015. 640 с.

2. Волкова М.В. Готовность к осуществлению морального выбора как базовая характеристика нравственно устойчивой личности. Мир науки, культуры, образования. 2011. № 4. С. 163-165.

3. Емельянова Т.П. Профессиональная ответственность в обыденном сознании студентов-энергетиков. Знание. Понимание. Умения. 2013. № 2. URL: http://www.zpu-Journal.ru/2013/2/Emelianova Professional-Responsibility-Student.

4. Кочетова И.Д. Создание условий для развития социальной ответственности у студентов как одно из приоритетных направлений в системе высшего профессионального образования. Мир науки, культуры, образования. 2010. № 6 (25). С. 126-130.

5. Лукач О.М. Формування моральної культури студентів вищих педагогічних навчальних закладів у позааудиторній діяльності : автореф. дис. ... канд. пед. наук : 13.00.07. Київ, 2012. 20 с.

6. Тернопільська В.І. Сучасні тенденції мотивації навчально-професійної діяльності студентів. Вісник Національного університету оборони України. Київ : НУОУ, 2012. Вип. 5 (30). С. 141-144.

7. Тернопільська В.І. Структура професійної компетентності майбутнього фахівця. Науковий вісник Мелітопольського державного педагогічного університету. Серія «Педагогіка». 2012. № 9. C. $208-213$.

8. Тернопільська В.І. Підготовка вчителя до формування моральної свідомості старшокласника. 1025-річчя історії освіти в Україні: традиції, сучасність та перспективи : зб. матер. міжнар. наук. конфр., м. Київ, 22 травня 2014 р. С. 58-65. 